\title{
Apparent Widespread Decline of the Boreal Chorus Frog (Pseudacris maculata) in Eastern Ottawa
}

\author{
DAVid C. SEburn ${ }^{1,4}$, KARI Gunson ${ }^{2}$, and Frederick W. SCHUEleR ${ }^{3}$ \\ ${ }^{1}$ Seburn Ecological Services, 2710 Clarenda Street, Ottawa, Ontario K2B 7S5 Canada \\ ${ }^{2}$ Eco-Kare International, 644 Bethune Street, Peterborough, Ontario K9H 4A3 Canada \\ ${ }^{3}$ Bishops Mills Natural History Centre, RR\#2, Bishops Mills, Ontario K0G 1T0 Canada \\ ${ }^{4}$ Corresponding author: davidseburn@sympatico.ca
}

Seburn, David C., Kari Gunson, and Frederick W. Schueler. 2014. Apparent widespread decline of the Boreal Chorus Frog (Pseudacris maculata) in eastern Ottawa. Canadian Field-Naturalist 128(2): 151-157.

The Boreal Chorus Frog (Pseudacris maculata) was once common in the eastern Ottawa area. To assess its current status, we conducted auditory surveys at 184 wetlands in 2011 and 2012. Boreal Chorus Frogs were heard at only five (2.7\%) of the surveyed sites. These five sites were spatially aggregated, with only $0.5-7.5 \mathrm{~km}$ between any two sites. Sites occupied by Boreal Chorus Frogs in eastern Ottawa were surrounded by significantly greater agricultural cover (at 1.0-, 1.5-, and 2.0-km radii), less forest cover (1.0- and 2.0-km radii), and less wetland cover (1.5- and 2.0-km radii) than occupied sites in western Ottawa. Sites in eastern Ottawa that were apparently unoccupied were surrounded by significantly greater agricultural cover (only at the 2.0-km radius), similar forest cover (all radii), and less wetland cover (all radii) compared with occupied sites in western Ottawa. Boreal Chorus Frog populations are commonly subject to extirpation resulting from stochastic events. The reduced wetland cover in eastern Ottawa may be accompanied by reduced wetland connectivity, making recolonization of wetlands difficult or impossible. Our data do not show whether wetland connectivity has been reduced, but future research should address this important topic.

Key Words: Boreal Chorus Frog; Pseudacris maculata; amphibian decline; Ottawa; Ontario; amphibian habitat; wetland connectivity

\section{Introduction}

Amphibian populations are known to be declining around the world (Wake and Vrendenburg 2008; Collins and Crump 2009; Collins 2010). A global assessment of all known amphibian species revealed that a third were threatened with extinction (Stuart et al. 2004). Although multiple causes have been identified, land use change resulting in habitat destruction is the leading cause of amphibian decline and extinction (Collins and Crump 2009; Collins 2010). Amphibian populations have also declined within protected areas where habitat destruction is not a threat. Such declines have been linked to numerous factors including introduced fish species (e.g., Knapp and Matthews 2000), disease (e.g., Rachowicz et al. 2006), pesticide drift (e.g., Davidson 2004), and climate change leading to reduced hydroperiod in temporary wetlands (e.g., McMenamin et al. 2008). In addition, sublethal effects of contaminants such as pesticides may make amphibians more susceptible to diseases (e.g., Davidson et al. 2007).

In eastern Ontario and western Quebec the Boreal Chorus Frog (Pseudacris maculata), formerly assigned to the species Western Chorus Frog (P. triseriata), has undergone substantial declines. It was once considered common southeast of Montréal (Bleakney 1959), but now appears completely absent from that area (Daigle 1997) and is extremely rare in Quebec (Desroches and Rodrigue 2004; COSEWIC 2008*). It has also become less widespread in areas of northern New York state (Gibbs et al. 2005; Corser et al. 2012) and eastern
Ontario near Cornwall (Seburn et al. 2008) and appears to have been extirpated from Vermont (Andrews 2013). Largely as a result of declines in Quebec, the Great Lakes/St. Lawrence-Canadian Shield population (under the name Western Chorus Frog) was designated threatened by the Committee on the Status of Endangered Wildlife in Canada (COSEWIC 2008*).

The trilling chorus frogs form a clade of closely related species within the genus Pseudacris (Moriarty and Cannatella 2004). A range-wide analysis of the mitochondrial DNA of trilling chorus frogs substantially revised our understanding of species limits in this group and determined that populations in eastern Ontario and western Quebec should be assigned to the Boreal Chorus Frog species (Lemmon et al. 2007). These taxonomic changes have been widely accepted (e.g., Corser et al. 2012; Dodd 2013), which requires that the literature on trilling chorus frogs be examined carefully to determine the current species allocation. Even recent papers (e.g., Sacerdote and King, in press) do not always follow the current taxonomy.

Recent surveys of the Boreal Chorus Frog in eastern Ontario have produced mixed results. Boreal Chorus Frogs were detected at only $5 \%$ of historical locations surveyed in the Cornwall area (Seburn et al. 2008), yet were found at two-thirds of historical locations in western Ottawa (Seburn and Gunson 2011), approximately $100 \mathrm{~km}$ away. The cause (or causes) of the declines remains unknown. Although wetland destruction is a major threat in some areas of Quebec (Daigle 1997; 
Picard and Desroches 2004*), populations have also been lost in areas where wetlands remain (Gibbs et al. 2005, Seburn et al. 2008, Seburn and Gunson 2011).

The Boreal Chorus Frog is known to have been widespread east of urban Ottawa during the late 1950s and early 1960s, although precise locations are mainly lacking. Knowledge of the distribution is based largely on surveys conducted by herpetologist Sherman Bleakney (1959) and Anne and Garnet Hanes (personal communication) (Figure 1). The agonistic or territorial call of a Spring Peeper (Pseudacris crucifer), which is also a trill (COSEWIC 2008*), can be confused with the call of the Boreal Chorus Frog, but it is unlikely that the experienced surveyors of the 1950s confused these two species.

The first indication that Boreal Chorus Frogs were rare east of urban Ottawa resulted from a survey conducted by one of us (FWS) along with Aleta Karstad (Bishops Mills Natural History Centre) and the late Mike Rankin (Canadian Museum of Nature) from 27 to 30 April 1997. Although Spring Peepers were detected at 34 sites, Boreal Chorus Frogs were detected at only two sites (FWS, unpublished data). To assess the current distribution of the species across this area, we undertook extensive auditory surveys of roadside wetlands and flooded ditches. We hypothesized that land cover variables, particularly differences in wetland, forest, and cropland cover, might explain why the Boreal Chorus Frog was rare in eastern Ottawa and beyond compared with western Ottawa. As nitrate levels of $10 \mathrm{mg} / \mathrm{L}$ or more can cause significant mortality of
Western Chorus Frog tadpoles (Hecnar 1995), we obtained surface water-quality data to determine whether nitrate contamination was contributing to local Boreal Chorus Frog decline.

\section{Study Area and Methods}

All surveys were conducted in suburban and rural eastern Ottawa and western Prescott and Russell county (Figure 2), an area of just over $800 \mathrm{~km}^{2}$. Daytime auditory surveys were conducted during the calling season of the Boreal Chorus Frog in 2011 (11, 12, 19, 22, and 27 April) and 2012 (20, 21, 22 March and 12, 13, and 18 April). A known site with Boreal Chorus Frogs in western Ottawa was visited at the start of each survey to confirm calling was occurring that day. Although Boreal Chorus Frogs in some populations may not call consistently during the day (FWS, personal observation), diurnal surveys in western Ottawa suggest that calling is widespread even among small populations (Seburn and Gunson 2011). Auditory surveys were conducted at wetlands and flooded ditches visible from roadsides, with the exception of a few locations in public parks where wetlands away from the road could be monitored. Surveys lasted 2-5 minutes per site depending on weather conditions and traffic noise.

We obtained records of 2012 surface water $(0.5 \mathrm{~m}$ depth) nitrate and nitrite levels from monitoring stations across Ottawa from the City of Ottawa. Because nitrate can be reduced to nitrite in biological systems (Hecnar 1995), we pooled the readings for both compounds for our analyses. As the City of Ottawa moni-

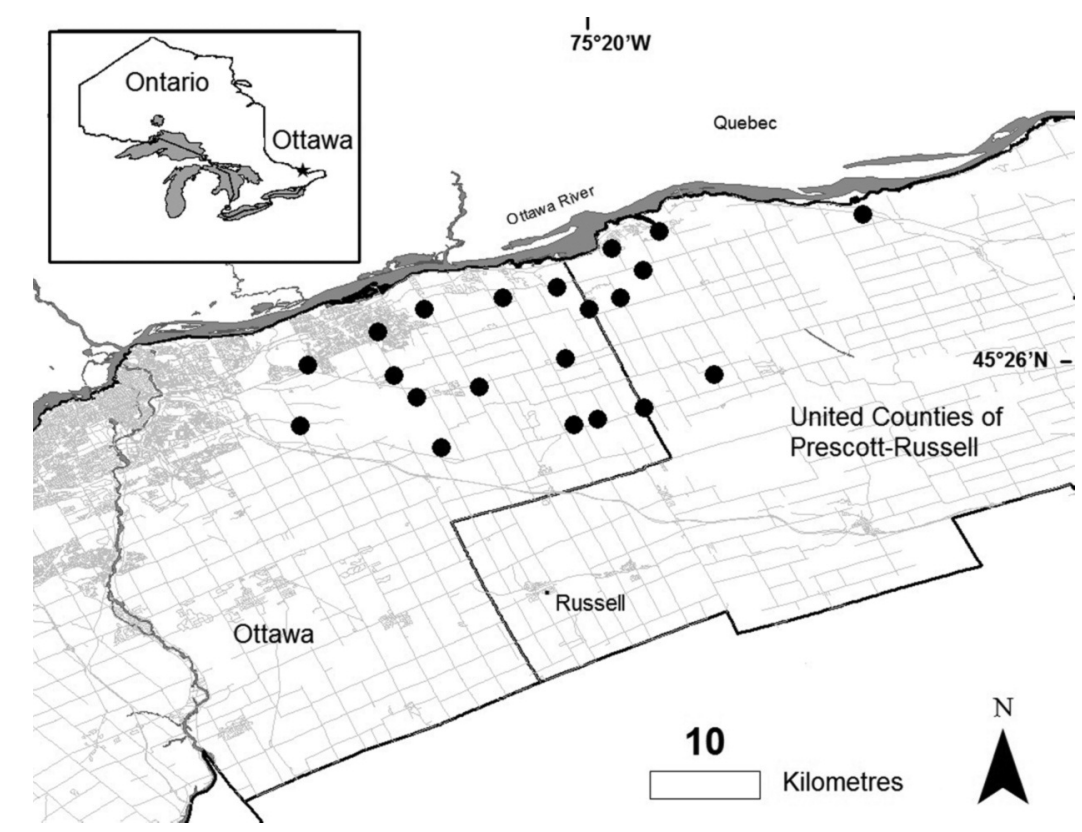

FIgURE 1. Historical records of the Boreal Chorus Frog (Pseudacris maculata) in eastern Ottawa and western Prescott and Russell. Localities were approximated from an unpublished map prepared by Anne and Garnet Hanes that included sites from their auditory surveys conducted in 1962 and records from Bleakney (1959) and the Canadian Museum of Nature. 


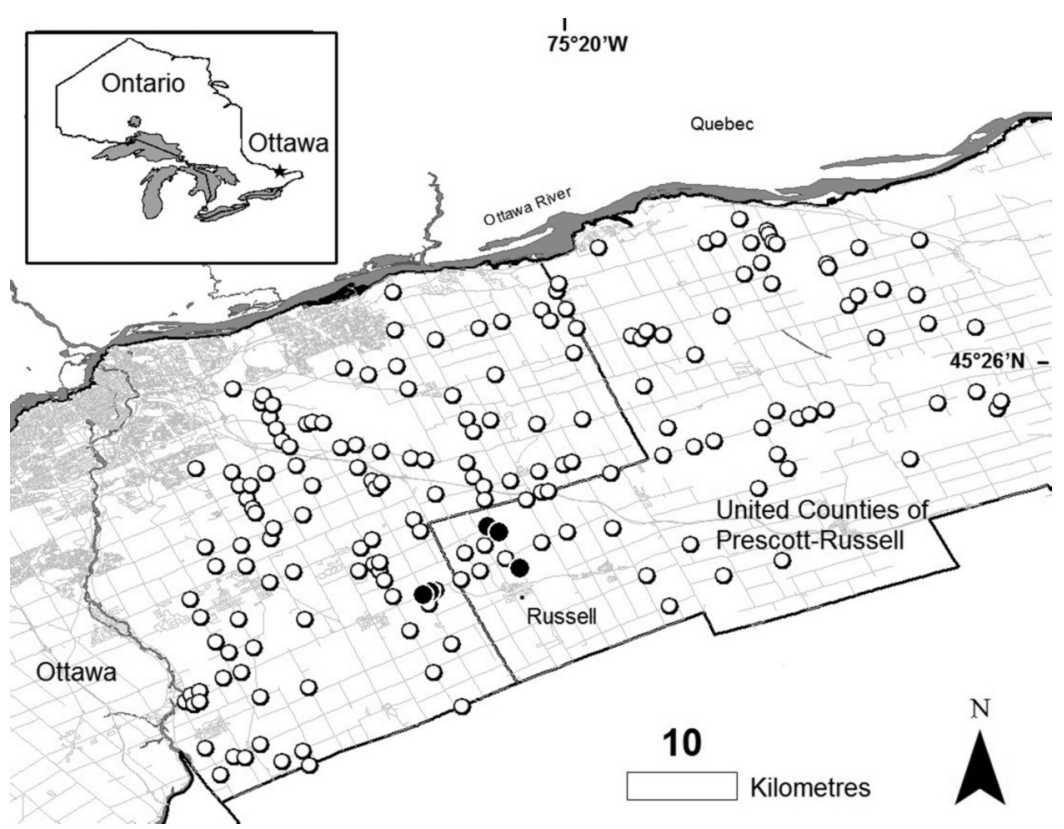

FiguRE 2. Location of 184 sites, at which auditory surveys were conducted in spring 2011 or 2012 or both, in eastern Ottawa and western Prescott and Russell. Open circles indicate sites where the Boreal Chorus Frog (Pseudacris maculata) was not detected; filled circles indicate the five sites where it was detected.

tors water quality a number of times during the year at each monitoring station, we took the highest combined reading of nitrate and nitrite for each station.

The Ontario Land Cover Data Base, 1st edition (Spectranalysis 1999*) was used to distinguish types of agricultural cover, specifically to separate old field/ pasture (a habitat that can support Boreal Chorus Frogs) from cropland (a habitat not suitable for Boreal Chorus Frogs). This database uses spectral character obtained from satellite images to classify land cover. Land use information was also obtained from the Southern Ontario Land Resource Information System (SOLRIS). The layer represents the landscape in $15 \mathrm{~m} \times 15 \mathrm{~m}$ pixels and is derived from a combination of satellite images, topographic maps, and aerial photographs from 2000-2003 (OMNR 2007*).

Three land use classes were used for analyses: forest cover ( $>60 \%$ tree cover, including plantations), wetlands ( $\geq 0.5$ ha in area), and agriculture (a broad category that includes intensive croplands as well as old fields and forest opening). We calculated the percentage of land devoted to each land use class for areas of radii $0.5,1.0,1.5$ and $2.0 \mathrm{~km}$ around each survey site. Land use variables on a larger scale may be correlated with frog landscape ecology (e.g., Gibbs et al. 2005), but in this case, a larger radius would result in some areas extending across the Ottawa River into adjacent Quebec, which did not seem ecologically meaningful. Land use data from sites in eastern Ottawa were compared with known Boreal Chorus Frog sites in western
Ottawa (Seburn and Gunson 2011). ArcMap 10.0 (Esri, Redlands, Cal.) was used for all spatial analyses and Minitab 8.3 (Minitab Inc., State College, Pennsylvania) for all statistical analyses.

\section{Results}

Auditory surveys were conducted at 144 locations in eastern Ottawa and western Prescott and Russell in 2011. In 2012, auditory surveys were conducted at 48 of the 144 sites (33.3\%) surveyed in 2011 as well as 40 additional sites in the area. In total, 184 sites were surveyed at least once during the two years (Figure 2). No Boreal Chorus Frogs were heard at any location in eastern Ottawa and western Prescott and Russell in 2011. One of us (FWS) heard Boreal Chorus Frogs calling near Russell during other amphibian surveys on 23 March, 2012 (Karstad et al. 2012; Schueler and Karstad 2012*). Subsequent surveys focused on that area to attempt to locate additional sites with Boreal Chorus Frogs. In total, Boreal Chorus Frogs were heard at five of the 184 sites (2.7\%) surveyed. Eight of the 48 sites (16.7\%) surveyed in both 2011 and 2012 had no standing water in 2012. One additional 2011 site was in the process of being tile drained when surveyed in 2012. Only one of the 48 sites (2.1\%) surveyed in both years had Boreal Chorus Frogs calling in 2012 but not 2011.

Maximum combined nitrate and nitrite level in surface water was $6.6 \mathrm{mg} / \mathrm{L}$ in eastern Ottawa and $6.2 \mathrm{mg} / \mathrm{L}$ in western Ottawa. There was no significant difference 
between the combined nitrate and nitrite levels in eastern Ottawa (median $=1.6 \mathrm{mg} / \mathrm{L}, n=34)$ and in western Ottawa $($ median $=1.7 \mathrm{mg} / \mathrm{L}, n=25 ; W=816.0, P=$ $0.315)$.

Ground truthing of cropland cover identified by the Ontario Land Cover Data Base indicated that this database was not reliable. For example, one known Boreal Chorus Frog site in an old field habitat was classified as $59 \%$ cropland. Therefore, all subsequent analyses used only the SOLRIS database.

The five eastern Ottawa sites with Boreal Chorus Frogs were clustered in three patches in an area near Russell (Figure 2). The distance between these occupied sites ranged from $0.5 \mathrm{~km}$ to $7.5 \mathrm{~km}$, and all sites were separated by at least one road. Despite this spatial aggregation, land use varied across the five sites. For the surrounding area within a $1.0-\mathrm{km}$ radius, median agricultural cover was $64.8 \%$ (range: $52.6-75.0 \%$ ), median forest cover was 3.7\% (range: $2.7-23.4 \%$ ), and median wetland cover was $11.2 \%$ (range: $3.6-28.2 \%$ ).
The occupied sites in eastern Ottawa had significantly greater agricultural cover (within a 1.0-, 1.5-, and 2.0$\mathrm{km}$ radii), less forest cover (1.0- and $2.0-\mathrm{km}$ radii), and less wetland cover (1.5- and $2.0-\mathrm{km}$ radii) than occupied sites in western Ottawa (Table 1). Sites in eastern Ottawa that were apparently unoccupied had significantly greater agricultural cover (only for a 2.0$\mathrm{km}$ radius), no significant difference in forest cover (all radii), and less wetland cover (all radii) compared with occupied sites in western Ottawa (Table 2). Many of the eastern Ottawa sites had low percentages of wetland cover. For example, although median wetland cover values for a $2.0-\mathrm{km}$ radius differed by only $2.1 \%$, $30 \%$ of eastern Ottawa sites had $<10 \%$ wetland cover, compared with only $14 \%$ of the western Ottawa sites.

Occupied sites in eastern Ottawa had greater agricultural cover $(2.0-\mathrm{km}$ radius only) than apparently unoccupied sites in eastern Ottawa, but there were no significant differences in forest or wetland cover for all radii (Table 3 ).

TABLE 1. Land use surrounding sites with Boreal Chorus Frogs (Pseudacris maculata) in eastern Ottawa $(n=5)$ and western Ottawa $(n=42)$ at $0.5-, 1.0-, 1.5-$, and $2.0-\mathrm{km}$ radii. Median percentages were compared using the non-parametric MannWhitney test $(W)$. Numbers in bold indicate a significant difference between eastern and western occupied sites $(P<0.05)$.

\begin{tabular}{lccccc}
\hline \hline $\begin{array}{l}\text { Land } \\
\text { use class }\end{array}$ & $\begin{array}{c}\text { Radius } \\
(\mathrm{km})\end{array}$ & $\begin{array}{c}\text { Eastern Ottawa } \\
\text { sites (median \%) }\end{array}$ & $\begin{array}{c}\text { Western Ottawa } \\
\text { sites (median \%) }\end{array}$ & $W$ & $P$ \\
\hline Agriculture & 0.5 & 67.4 & 45.0 & 954 & 0.0649 \\
& 1.0 & $\mathbf{6 4 . 8}$ & $\mathbf{4 6 . 5}$ & 948 & 0.0401 \\
& 1.5 & $\mathbf{6 5 . 4}$ & $\mathbf{4 7 . 2}$ & 932 & 0.0092 \\
Forest & 2.0 & $\mathbf{6 9 . 0}$ & $\mathbf{4 8 . 1}$ & 922 & 0.0032 \\
& 0.5 & $\mathbf{3 . 7}$ & 17.0 & 1061 & 0.0701 \\
& 1.0 & 6.0 & $\mathbf{1 8 . 1}$ & 1066 & 0.0473 \\
Wetland & 1.5 & $\mathbf{4 . 7}$ & $\mathbf{2 2 . 6}$ & 1064 & 0.0555 \\
& 2.0 & 9.4 & 17.1 & 1073 & 0.0261 \\
& 0.5 & $\mathbf{2 . 7}$ & 18.6 & 1061 & 0.0701 \\
& 1.0 & $\mathbf{9 . 3}$ & $\mathbf{1 9 . 6}$ & 1049 & 0.1623 \\
& 1.5 & $\mathbf{1 8 . 1}$ & 1067 & 0.0435 \\
\hline \hline
\end{tabular}

TABLE 2. Land use surrounding apparently unoccupied sites in eastern Ottawa $(n=179)$ and sites with Boreal Chorus Frogs (Pseudacris maculata) in western Ottawa $(n=42)$ at 0.5-, 1.0-, 1.5-, and 2.0-km radii. Median percentages were compared using the non-parametric Mann-Whitney test $(W)$. Numbers in bold indicate a significant difference between apparently unoccupied eastern and occupied western sites $(P<0.05)$.

\begin{tabular}{lccccc}
\hline \hline $\begin{array}{l}\text { Land } \\
\text { use class }\end{array}$ & $\begin{array}{c}\text { Radius } \\
(\mathrm{km})\end{array}$ & $\begin{array}{c}\text { Unoccupied sites } \\
\text { in eastern Ottawa } \\
(\text { median \%) }\end{array}$ & $\begin{array}{c}\text { Occupied sites } \\
\text { in western Ottawa } \\
(\text { median \%) }\end{array}$ & $W$ & $P$ \\
\hline Agriculture & 0.5 & 52.9 & 45.0 & 20469 & 0.1079 \\
& 1.0 & 54.5 & 46.5 & 20346 & 0.2014 \\
& 1.5 & 52.5 & 47.2 & 20488 & 0.0972 \\
Forest & 2.0 & $\mathbf{5 0 . 8}$ & $\mathbf{4 8 . 1}$ & 20606 & 0.0483 \\
& 0.5 & 14.0 & 17.0 & 19413 & 0.2219 \\
& 1.0 & 17.5 & 18.1 & 19507 & 0.3324 \\
& 1.5 & 17.0 & 21.6 & 19316 & 0.1385 \\
Wetland & 2.0 & 17.1 & $\mathbf{1 7 . 1}$ & 19203 & 0.0743 \\
& 0.5 & $\mathbf{1 1 . 1}$ & $\mathbf{1 8 . 6}$ & 18951 & 0.0139 \\
& 1.0 & $\mathbf{1 3 . 0}$ & $\mathbf{1 9 . 6}$ & 18975 & 0.0166 \\
& 1.5 & $\mathbf{1 4 . 3}$ & $\mathbf{1 8 . 1}$ & 18790 & 0.0046 \\
& 2.0 & $\mathbf{1 6 . 0}$ & & & 0.0038 \\
\hline \hline
\end{tabular}


TABLE 3. Land use surrounding sites in eastern Ottawa with $(n=5)$ and apparently without $(n=179)$ Boreal Chorus Frogs (Pseudacris maculata) at 0.5-, 1.0-, 1.5-, and 2.0-km radii. Median percentages were compared using the non-parametric MannWhitney test $(W)$. Numbers in bold indicate a significant difference between occupied and unoccupied sites $(P<0.05)$.

\begin{tabular}{lccccc}
\hline \hline $\begin{array}{l}\text { Land use } \\
\text { class }\end{array}$ & $\begin{array}{c}\text { Radius } \\
(\mathrm{km})\end{array}$ & $\begin{array}{c}\text { Occupied sites } \\
(\text { median \%) }\end{array}$ & $\begin{array}{c}\text { Unoccupied sites } \\
(\text { median \%) }\end{array}$ & $W$ & $P$ \\
\hline Agriculture & 0.5 & 67.4 & 52.9 & 16448 & 0.3534 \\
& 1.0 & 64.8 & 54.5 & 16407 & 0.2016 \\
& 1.5 & 65.4 & 52.5 & 16371 & 0.1133 \\
Forest & 2.0 & $\mathbf{6 9 . 0}$ & $\mathbf{5 0 . 8}$ & 16320 & 0.0436 \\
& 0.5 & 9.9 & 14.0 & 16698 & 0.2333 \\
& 1.0 & 3.7 & 17.5 & 16720 & 0.1679 \\
& 1.5 & 4.7 & 17.0 & 16711 & 0.1927 \\
Wetland & 2.0 & 9.4 & 17.1 & 16742 & 0.1172 \\
& 0.5 & 11.2 & 11.1 & 16655 & 0.4089 \\
& 1.0 & 9.7 & 14.0 & 16628 & 0.5512 \\
& 1.5 & 9.3 & 16.0 & 16669 & 0.3447 \\
& 2.0 & & & 16745 & 0.1114 \\
\hline \hline
\end{tabular}

\section{Discussion}

Our surveys indicate that the Boreal Chorus Frog is rare in eastern Ottawa, and a decline seems to have occurred since the 1950s. Although our surveys undoubtedly failed to detect some populations, our survey technique has proven successful in the past. Using this technique, we found 30 previously undocumented Boreal Chorus Frog locations in western Ottawa (Seburn and Gunson 2011). One limitation of our survey technique is that auditory surveys were largely limited to wetlands visible from roads, and Boreal Chorus Frog populations may persist away from roads. However, only about $27 \%$ of the study area is more than $500 \mathrm{~m}$ from a road, the approximate distance at which a chorus can be heard.

Six broad classes of threats have been identified as causes of amphibian declines: commercial use (i.e., collecting), introduced/exotic species, land use change, contaminants, climate change, and infectious diseases (Collins and Crump 2009). Commercial use can be ruled out because the Boreal Chorus Frog is too small to be easily collected by humans. It is also unlikely that exotic species have caused the decline. Although introduced plants such as Purple Loosestrife (Lythrum salicaria) and European Common Reed (Phragmites australis ssp. australis) have altered wetlands, they are common across all of eastern Ontario including areas where the Boreal Chorus Frog remains widespread. The metabolite emodin from the invasive European Buckthorn (Rhamnus cathartica) can cause mortality of Boreal Chorus Frog embryos (Sacerdote and King, in press), but this shrub appears common in both eastern and western Ottawa (Soper and Heimburger 1985). It also seems unlikely that climate change would cause Boreal Chorus Frogs to decline in eastern Ottawa but not nearby in western Ottawa. This leaves three broad classes of threats: contaminants, infectious disease, or land use change.

Contaminants can be lethal to the Boreal Chorus Frog. Exposure to low levels (700 ppb) of the glyphosate herbicide Roundup WeatherMax (Monsanto Cana- da Inc., Winnipeg, Manitoba) resulted in $80 \%$ mortality of Boreal Chorus Frog tadpoles (Williams and Semlitsch 2010). The high mortality rate is likely a result of the unique surfactant in the product, as Roundup Original (Monsanto Canada Inc.) did not cause high levels of mortality (Williams and Semlitsch 2010). However, Roundup WeatherMax was not available in Canada until the early 2000s, and the Boreal Chorus Frog was declining before that (e.g., Daigle 1997), so it likely does not explain the declines. Nitrate contamination of surface waters from nitrogen-based fertilizers can also cause significant mortality of Western Chorus Frog tadpoles at levels of $10 \mathrm{mg} / \mathrm{L}$ or more (Hecnar 1995), but surface water data from the City of Ottawa suggest that nitrate levels are consistently below $10 \mathrm{mg} / \mathrm{L}$, although it is possible they were higher in the past.

Infectious disease is another possibility. The chytrid fungus Batrachochytrium dendrobatidis has been detected in over 50 countries and over 500 species of amphibians (Olson et al. 2013). Infection can lead to chytridiomycosis, a fatal disease implicated in the decline of over 200 amphibian species (Fisher et al. 2009). The fungus has been detected in Boreal Chorus Frogs in southern Quebec, but no increased mortality or morbidity of frogs was observed (Ouellet et al. 2005). Thus, although chytridiomycosis cannot be excluded, again it is unlikely that it would affect frogs in eastern Ottawa but not western Ottawa.

Given that land use change resulting in habitat destruction is the leading cause of amphibian decline (Collins and Crump 2009; Collins 2010), it seems plausible that habitat loss is a prime driver of the decline in the Boreal Chorus Frog. The fact that unoccupied sites in eastern Ottawa had significantly lower wetland cover values at all spatial scales compared with occupied sites in western Ottawa (Table 2) suggests that landscape differences could explain the apparent decline; however, we have no direct evidence that wetland cover in eastern Ottawa has been reduced since the 1950s. One problem with this hypothesis is that occupied sites in eastern Ottawa did not differ in wet- 
land cover from apparently unoccupied sites in eastern Ottawa (Table 3). Local conditions, such as hydrology, wetland configuration or connectivity, and the number of wetlands too small to be detected by our analyses, could explain the localized persistence of Boreal Chorus Frogs at occupied sites in eastern Ottawa. Wetland cover in all of Ottawa-Carleton declined from an estimated $47.2 \%$ circa 1800 to an estimated $13.2 \%$ in 1967 , but no significant change in wetland cover occurred from 1967 to 2002 (Ducks Unlimited 2010*). Intensive farming practices in the 1950s and 1960s likely resulted in wetland loss, although we cannot document the extent of any loss.

The Boreal Chorus Frog is a short-lived frog, with more than $90 \%$ of adults breeding only once (Whiting 2004). Individuals typically remain within $275 \mathrm{~m}$ of breeding ponds (Desroches et al. 2001*) and wetland occupancy is correlated with the number of neighbouring occupied wetlands (Scherer et al. 2012). In the closely related Western Chorus Frog, stochastic events, such as premature drying of breeding ponds, can lead to annual extinction rates exceeding $50 \%$ (Werner et al. 2009). In addition, dry summers may limit successful immigration of Boreal Chorus Frogs to unoccupied wetlands (Schueler and Karstad 2013*). These factors suggest that wetland connectivity is important in ensuring that re-colonization can occur from neighbouring populations. Such lack of connectivity appears to be a factor in western Ottawa where isolated populations are more apt to become extirpated (Seburn and Gunson 2011).

Boreal Chorus Frogs likely persist across the landscape as a metapopulation (e.g., Gill 1978). If reduced wetland cover results in fewer wetlands, then it is plausible that wetland connectivity is reduced in eastern Ottawa. For example, a simulation of the loss of small wetlands in Maine demonstrated that this would result in a loss of total wetland area of $19 \%$, but increase the inter-wetland distance by $67 \%$ (Gibbs 1993). Whether wetland connectivity has been reduced in eastern Ottawa cannot be explicitly tested using SOLRIS data, as wetlands smaller than 0.5 ha cannot be identified (OMNR 2007*). A detailed examination of wetland distribution and abundance in eastern and western Ottawa is required to determine whether wetland connectivity could explain the apparent decline of the Boreal Chorus Frog.

The most similar species that co-occurs with the Boreal Chorus Frog is the congeneric Spring Peeper (Pseudacris crucifer), which remains widespread in eastern Ottawa (DS, personal observation). Why should one species decline and the other remain widespread? In general, the closely related Western Chorus Frog is more common in ephemeral sites that tend to lack aquatic predators, whereas the Spring Peeper is more common in less ephemeral sites with more abundant aquatic predators (Skelly 1996). This also appears to be the case for the Boreal Chorus Frog in eastern Ontario (DS, personal observation). Small, ephemeral wetlands are often first lost when cropland expands and the result could be a landscape more suited to Spring Peepers than Boreal Chorus Frogs.

There is compelling evidence that the Boreal Chorus Frog has declined across much of eastern Ottawa and western Prescott and Russell. The lack of wetland cover in eastern Ottawa may have contributed to this decline, although additional research on abundance and distribution of small wetlands is required. Finding explanations for the widespread persistence of western Ottawa populations may also provide guidance for the conservation of this species.

\section{Acknowledgements}

Mike Oldham of the Natural Heritage Information Centre of the Ontario Ministry of Natural Resources graciously provided data from the Ontario Herpetofaunal Atlas. We thank Garnet Hanes for the data and maps from the surveys he conducted with the late Anne Hanes. Funding was provided by the Canadian Wildlife Federation. This paper benefited from review comments from Carolyn Seburn and four anonymous reviewers.

\section{Documents Cited (marked * in text)}

COSEWIC (Committee on the Status of Endangered Wildlife in Canada). 2008. COSEWIC assessment and update status report on the Western Chorus Frog Pseudacris triseriata Carolinian population and Great Lakes/St. Lawrence - Canadian Shield population in Canada. COSEWIC, Ottawa, Ontario. vii +47 pages.

Desroches, J. F., D. Pouliot, and S. Côté. 2001. Évaluation de l'efficacité de différentes méthodes de capture pour la rainette faux-grillon de l'Ouest (Pseudacris triseriata) au Québec. En collaboration avec le Comité du marais de Kingsbury. Société de la faune et des parcs du Québec, Québec, Québec.

Ducks Unlimited. 2010. Southern Ontario wetland conversion analysis: final report. Ducks Unlimited, Barrie, Ontario.

OMNR (Ontario Ministry of Natural Resources). 2007. SOLRIS: accuracy assessment report. Submitted to the Inventory Monitoring and Assessment Section, Ontario. Available: http://equinox.uwo.ca/Docfiles/OGDE/SOLRIS/ SOLRISAccuracyAssessmentAreaA-FAQ.PDF (accessed April 2011).

Picard, I., and J. F. Desroches. 2004. Situation de la Rainette faux-grillon de l'Ouest (Pseudacris triseriata) en Montérégie-Inventaire printanier 2004. En collaboration avec le Centre d'information sur l'environnement de Longueuil, Longueuil, Quebec. 50 pages.

Schueler, F. W., and A. Karstad. 2012. Early spring cryptic species expedition: northern range limits of the "Western" Chorus Frog. Submitted to the Canadian Wildlife Federation, Ottawa, Ontario. 25 pages.

Schueler, F. W., and A. Karstad. 2013. Preliminary results: do dry springs and moist Augusts favour Chorus Frogs in Bishops Mills, Ontario? Abstract. Canadian Amphibian and Reptile Conservation Network annual meeting, Orford, Quebec, 13-15 September 2013.

Spectranalysis. 1999. Ontario Land Cover Data Base — user's manual. Ontario Ministry of Natural Resources, Toronto, Ontario. 


\section{Literature Cited}

Andrews, J. S. 2013. The Vermont Reptile and Amphibian Atlas. Update edition. Self-published, Middlebury, Vermont.

Bleakney, S. 1959. Postglacial dispersal of the western chorus frog in eastern Canada. Canadian Field-Naturalist 73(4): 197-205.

Collins, J. P. 2010. Amphibian decline and extinction: what we know and what we need to learn. Diseases of Aquatic Organisms 92: 93-99.

Collins, J. P., and M. L. Crump. 2009. Extinction in Our Time: Global Amphibian Decline. Oxford University Press, Oxford, UK.

Corser, J. D., K. J. Roblee, and G. Johnson. 2012. Shifting status and distribution of range margin chorus frog (Pseudacris) populations in eastern Great Lakes watersheds. Journal of Great Lakes Research 38: 806-811.

Daigle, C. 1997. Distribution and abundance of the Chorus Frog, Pseudacris triseriata, in Quebec. Pages 73-77 in Amphibians in Decline: Canadian Studies of a Global Problem, Herpetological Conservation, Volume 1. Edited by D. M. Green. Society for the Study of Amphibians and Reptiles, St. Louis, Missouri.

Davidson C. 2004. Declining downwind: amphibian population declines in California and historical pesticide use. Ecological Applications 14: 1892-1902.

Davidson, C., M. F. Benard, H. B. Shaffer, J. M. Parker, C. O'Leary, J. M. Conlon, and L. A. Rollins-Smith. 2007. Effects of chytrid and carbaryl exposure on survival, growth and skin peptide defenses in Foothill Yellow-legged Frogs. Environmental Science and Technology 41: 1771-1776.

Desroches, J. F., and D. Rodrigue. 2004. Amphibiens et Reptiles du Québec et des Maritimes. Éditions Michel Quintin, Waterloo, Quebec

Dodd Jr., C. K. 2013. Frogs of the United States and Canada. 2 volumes. Johns Hopkins University Press, Baltimore, Maryland

Fisher, M. C., T. W. J. Garner, and S. F. Walker. 2009. Global emergence of Batrachochytrium dendrobatidis and amphibian chytridiomycosis in space, time, and host. Annual Review of Microbiology 63: 291-310.

Gibbs, J. P. 1993. Importance of small wetlands for the persistence of local populations of wetland-associated animals. Wetlands 13: 25-31.

Gibbs, J. P., K. K. Whiteleather, and F. W. Schueler. 2005. Changes in frog and toad populations over 30 years in New York state. Ecological Applications 15: 1148-1157.

Gill, D. E. 1978. The metapopulation ecology of the RedSpotted Newt, Notophthalmus viridescens (Rafinesque). Ecological Monographs 48: 145-166.

Hecnar, S. J. 1995. Acute and chronic toxicity of ammonium nitrate fertilizer to amphibians from southern Ontario. Environmental Toxicology and Chemistry 14: 2131-2137.

Karstad, A., F. W. Schueler, and C. Vetter. 2012. Island of Biodiversity: A Natural History of the North Russell Red Shale Hill. The Library of One Thing and Another, Bishops Mills, Ontario.

Knapp, R. A., and K. R. Matthews. 2000. Non-native fish introductions and the decline of the mountain yellowlegged frog from within protected areas. Conservation Biology 14: 428-438.

Lemmon, E. M., A. R. Lemmon, J. T. Collins, J. A. LeeYaw, and D. C. Cannatella. 2007. Phylogeny-based delimitation of species boundaries and contact zones in the trilling chorus frogs (Pseudacris). Molecular Phylogenetics and Evolution 44: 1068-1082.
McMenamin, S. K., E. A. Hadly, and C. K. Wright. 2008. Climatic change and wetland desiccation cause amphibian decline in Yellowstone National Park. Proceedings of the National Academy of Sciences 105: 16988-16993.

Moriarty, E. C., and D. C. Cannatella. 2004. Phylogenetic relationships of the North American chorus frogs (Pseudacris: Hylidae). Molecular Phylogenetics and Evolution 30: 409-420.

Olson, D. H., D. M. Aanensen, K. L. Ronnenberg, C. I. Powell, S. F. Walker, J. Bielby, T. W. J. Garner, G. Weaver, and M. C. Fisher. 2013. Mapping the global emergence of Batrachochytrium dendrobatidis, the amphibian chytrid fungus. PLOS ONE 8: e56802.

Ouellet, M., I. Mikaelian, B. D. Pauli, J. Rodrigue, and D. M. Green. 2005. Historical evidence of widespread chytrid infection in North American amphibian populations. Conservation Biology 19: 1431-1440.

Rachowicz, L. J., R. A. Knapp, J. A. T. Morgan, M. J. Stice, V. T. Vredenburg, J. M. Parker, and C. J. Briggs. 2006. Emerging infectious disease as a proximate cause of amphibian mass mortality. Ecology 87: 1671-1683.

Sacerdote, A. B., and R. B. King. In press. Direct effects of an invasive European Buckthorn metabolite on embryo survival and development in Xenopus laevis and Pseudacris triseriata. Journal of Herpetology.

Scherer, R. D., E. Muths, and B. R. Noon. 2012. The importance of local and landscape-scale processes to the occupancy of wetlands by pond-breeding amphibians. Population Ecology 54: 487-498.

Seburn, D. C., and K. Gunson. 2011. Has the Western Chorus Frog (Pseudacris triseriata) declined in western Ottawa, Ontario? Canadian Field-Naturalist 125: 220-226.

Seburn, D. C., C. N. L. Seburn, and W. F. Weller. 2008. A localized decline in the Western Chorus Frog, Pseudacris triseriata, in eastern Ontario. Canadian Field-Naturalist 122: $158-161$

Skelly, D. K. 1996. Pond drying, predators, and the distribution of Pseudacris tadpoles. Copeia 1996: 599-605.

Soper, J. H., and M. L. Heimburger. 1985. Shrubs of Ontario. Second printing, with revisions. Royal Ontario Museum, Toronto, Ontario.

Stuart, S., J. S. Chanson, N. A. Cox, B. E. Young, A. S. L. Rodrigues, D. L. Fishman, and R. W. Waller. 2004. Status and trends of amphibian declines and extinctions worldwide. Science 306: 1783-1786.

Wake, D. B., and V. T. Vredenburg. 2008. Are we in the midst of the sixth mass extinction? A view from the world of amphibians. Proceedings of the National Academy of Sciences, USA 105: 11 466-11 473.

Werner, E., R. A. Relyea, K. L. Yurewicz, D. K. Skelly, and C. J. Davis. 2009. Comparative landscape dynamics of two anuran species: climate-driven interaction of local and regional processes. Ecological Monographs 79: 503521.

Whiting, A. 2004. Population ecology of the western chorus frog, Pseudacris triseriata. MSc thesis, McGill University, Montréal, Quebec.

Williams, B. K., and R. D. Semlitsch. 2010. Larval responses of three midwestern anurans to chronic, low-dose exposures of four herbicides. Archives of Environmental Contamination and Toxicology 58: 819-827.

Received 1 November 2013

Accepted 15 December 2013 